\title{
Efisiensi dan Efektivitas Lembaga Amil Zakat Nasional
}

Studi pada Inisiatif Zakat Indonesia

\author{
Muhammad Burhanudin \\ Universitas Negeri Surabaya \\ muhammadburhanudin16@gmail.com
}

\author{
Rachma Indrarini \\ Universitas Negeri Surabaya \\ rachmaindrarini@unesa.ac.id
}

\begin{abstract}
Abstrak Indonesia merupakan salah satu negara dengan jumlah penduduk terbesar di dunia. Namun, penduduknya masih banyak yang tergolong miskin dan menjadi perhatian pemerintah untuk meminimalisir angka kemiskinan. Di sisi lain, Indonesia memiliki penduduk dengan mayoritas beragama islam terbesar. Hal ini merupakan peluang dalam mengoptimalkan peran zakat, infak, dan sedekah sebagai instrument fiskla islam dalam upaya menanggulangi masalah kemiskinan di masyarakat. Sebab itu perlu adanya lembaga pengelola untuk menghimpun dan menyalurkan dana ZIS masyarakat yang efisien dan efektif. Dengan ini, pentingnya pengukuran tingkat efisiensi dan efektivitas lembaga amil dalam pengelolaan dana ZIS. Pada penelitian ini, pengukuran efisiensi menggunakan metode Data Envelopment Analysis (DEA) dengan pendekatan intermediasi, asumsi CRS berorientasi input dan untuk mengukur efektivitas amil menggunakan rasio Allocation to Collection Ratio (ACR). Hasil penelitian ini menunjukkan bahwa LAZNAS Inisiatif Zakat Indonesia mengalami kinerja inefisiensi pada tahun 2016 sebesar 69,29\% sedangkan pada tahun 2017 dan tahun 2018 mengalami efisiensi sempurna 100\%. Untuk pengukuran tingkat efektivitasnya pada tahun 2016 mendapatkan skor $51 \%$ dan tahun 2017 mendapatkan skor 92\%, serta tahun 2018 memperoleh skor $96 \%$.
\end{abstract}

Kata Kunci Efisiensi, Efektivitas, Lembaga Amil Zakat Nasional

\section{PENDAHULUAN}

Indonesia merupakan Negara dengan jumlah penduduk terbanyak keempat dunia. Berdasarkan riset dari Worldometers, total populasi penduduk Indonesia tahun 2019 sebesar 269,1 juta jiwa (Databooks, 2019). Namun, masih banyak penduduk Indonesia yang masuk kateori penduduk miskin menurut Badan Pusat Statistik (BPS) yang perlu mendapat perhatian dari pemerintah. Data statistik mengungkapkan pada bulan Maret 2019 jumlah penduduk miskin di Indonesia sebesar 9,41\% dari jumlah total populasi (BPS, 2019). Kemiskinan masih menjadi polemik yang tak kunjung berlalu di Indonesia. Melihat problematika kemiskinan diatas, Islam sebagai agama rahmatallil'alamin memiliki alternatif solusi untuk permasalahan kemiskinan dengan instrumen zakat.

Indonesia, negara dengan populasi penduduk muslim terbesar dunia sampai saat ini. 
Dengan populasi mayoritas berpenduduk agama islam secara nasional bukan mustahil potensi zakat juga sangatlah besar dan seyogyanya dioptimalkan demi kemaslahatan bersama. Namun, BAZNAS mencatat bahwa potensi zakat di Indonesia di tahun 2018 mencapai angka 232 triliun rupiah namun yang berhasil terealisasi hanya sebesar 8,1 triliun rupiah (DataBooks, 2019). Hal ini selaras denga penelitian oleh Canggih, dkk (2017) yang mencoba menggali dan mengolah data terkait potensi dana zakat dan realisasinya di Indonesia selama rentang waktu 2011-2015.

Melihat kesenjangan yang ada antara potensi dan realisasi di lapangan diperlukan adanya formulasi untuk manajemen dana ZIS yang efektif dan efisien. Sesuai dengan amanat BAB I Ketentuan Umum tepatnya Pasal 3 UU Nomor 23 Tahun 2011, dibutuhkan sebuah kinerja efisien dan efektif dari sebuah lembaga amil guna kemanfaatan dapat diberdayakan dan dirasakan umat khususnya masyarakat mustahik.

\section{LANDASAN TEORI}

\subsection{Efisiensi}

Efisiensi menurut Kamus Besar Bahasa Indonesia, adalah ketepatan cara (usaha, kerja) dalam mengoperasikan suatu hal dengan tidak menyia-yiakan waktu, tenaga, dan biaya. Efisiensi adalah rasio antara output dengan input (Sulistiyani \& Rosidah, 2009). Ada tiga pendekatan yang dapat dilakukan terkait perhitungan seberapa efisien sebuah lembaga dalam menjalankan tugasnya:

a) Pendekatan Produksi, yaitu pendekatan ini menganggap amil sebagai pengelola dana/biaya untuk menghasilkan output dari dana yang berhasil terhimpun berupa penghimpunan dana zakat (Rusmini \& Aji, T.S, 2019).

b) Pendekatan Intermediasi, yaitu pendekatan ini menganggap amil sebagai lembaga penghubung (intermediator) dana antara golongan muzaki dengan masyarakat mustahik (Rusmini \& Aji, T.S, 2019).

c) Pendekatan Asset, yaitu pendekatan ini menganggap lembaga zakat sebagai penyalur kredit pinjaman yang hasil outputnya diukur dengan aset - aset yang dipunyai. Output dengan pendekatan ini berupa asset (Nurhasanah \& Lubis, 2017).

\subsection{Efektivitas}

Efektivitas berasal dari kata dasar efektif. Menurut KBBI, kata efektif mempunyai makna pengaruh, efek, dapat membawa hasil atau akibat. Efektivitas menekankan pada hasil yang dicapai, sedangkan efisiensi lebih melihat pada bagaiman cara mencapai hasil yang dicapai itu dengan membandingkan antara input dan output-nya (Siagian, 2001).

\subsection{Efisiensi dan Efektivitas Pada Lembaga Amil Zakat}

Pengukuran kinerja lembaga akan memberikan pijakan bagi manajemen lembaga untuk mengendalikan jalannya lembaga secara efektif dan efisien. Penelitian relevan terkait pengukuran efisiensi lembaga telah beberapa dilakukan sebelumnya. Penelitian oleh Indrarini dan Canggih (2019) dengan hasil penelitian menunjukkan bahwa sebagian besar dari perusahaan asuransi jiwa syariah dalam kinerjanya belum efisien pada periode 2012 - 2016 dan masih terdapat yang telah tercatat pada OJK namun tidak semua mempublikasikan laporan keuangannya. Metode pengukuran efisiensi lembaga terdapat berbagai macam terkait dengan model pendekatan, orientasi, dan 
asumsi yang digunakan. Model pendekatan pengukuran efisiensi dibagi menjadi tiga yaitu pendekatan produksi, intermediasi, dan asset. Orientasi yang digunakan terbagi menjadi orientasi input dan output tergantung sudut pandang mana yang akan dianalisa (Rusmini \& Aji, T.S, 2019). Asumsi pada pengukuran efisiensi terdapat dua yakni CRS dan VRS dimana keduanya memiliki asumsi yang berbeda (Coelli, dkk, 2005).

Dalam hal efektivitas lembaga, pada dasarnya menunjukkan pada taraf tercapainya hasil. Efektivitas menekankan pada hasil yang dicapai. Semakin banyak rencana yang dapat dicapai, semakin efektif pula kegiatan tersebut (Azizah, 2018). Penelitian oleh Azizah (2018) dengan hasil menunjukkan bahwa secara umum BAZNAS Kota Yogyakarta memiliki peningkatan kinerja yang efektif dari tahun ke tahun mulai tahun 2012-2015 dimana pada tahun 2015 menunjukkan kinerja yang paling efektif, yaitu mencapai tingkat highly effective dengan nilai ACR sebesar 103,22\%. Dalam pengukuran efektivitas lembaga pada umumnya menggunakan rasio ACR yang bersandar pada kriteria Zakat Core Principles (ZCP) Outlook Zakat Indonesia Puskaz BAZNAS.

\section{METODOLOGI PENELITIAN}

\subsection{Jenis Penelitian}

Penelitian yang diteliti oleh penulis ini merupakan penelitian jenis kuantitatif deskriptif. Dalam penelitian ini, penelitian kuantitatif digunakan untuk mengukur tingkat efesisensi dan efektivitas pada suatu lembaga sedangkan penelitian deskriptif digunakan untuk mendeskripsikan, menjelaskan, dan meringkas kinerja yang ada di LAZ yang diteliti.

\subsection{Sumber Data}

Penulis menggunakan sumber data berupa data sekunder. Sumber data sekunder yang dipakai dalam pengolahan data berupa laporan keuangan lembaga amil yang telah terpublikasikan di website resmi sebagai bentuk transparansi.

\subsection{Populasi dan Sampel}

Populasi dalam penelitian ini adalah lembaga amil zakat nasional yang telah resmi berdiri dan mendapat rekomendasi dari BAZNAS Pusat di Indonesia sebanyak 25 LAZNAS. Adapun sampel pada penelitian ini, yakni lembaga amil zakat nasional Inisiatif Zakat Indonesia. Penentuan sampel menggunakan teknik atau metode purposive sampling dimana peneliti menetapkan kriteria-kriteria tertentu:

1. LAZNAS yang telah resmi berdiri,

2. LAZNAS yang memperoleh rekomendasi dari BAZNAS Pusat sesuai yang terpublikasi di website BAZNAS,

3. LAZNAS yang memiliki laporan keuangan yang terpublikasi di website yang bersangkutan, dan

4. Lembaga zakat dengan jumlah penghimpunan terbanyak.

\subsection{Variabel Penelitian}

Variabel yang dipakai pada penelitian ini terdapat variabel input \& variabel output untuk pengukuran efisiensi dan variabel outcome untuk pengukuran efektivitas lembaga amil zakat.

Tabel 3.1 Variabel Input \& Variabel Output 
(Pengukuran Tingkat Efisiensi)

\begin{tabular}{|c|c|c|c|}
\hline Tahun & Variabel & Komponen & Jumlah \\
\hline \multirow[t]{3}{*}{2016} & \multirow[t]{2}{*}{ Input } & Biaya Operasional & Rp. 6.551.963.732,-- \\
\hline & & Dana ZIS Terhimpun & Rp. 62.550.073.983,- \\
\hline & Output & Dana ZIS Tersalurkan & Rp. 32.037.792.810,- \\
\hline \multirow[t]{3}{*}{2017} & \multirow[t]{2}{*}{ Input } & Biaya Operasional & Rp. 7.857.919.503,- \\
\hline & & Dana ZIS Terhimpun & Rp. 60.570.599.886,- \\
\hline & Output & Dana ZIS Tersalurkan & Rp. 55.453.648.037,- \\
\hline \multirow[t]{3}{*}{2018} & \multirow[t]{2}{*}{ Input } & Biaya Operasional & Rp. 11.287.389.442,- \\
\hline & & Dana ZIS Terhimpun & Rp. 78.853.112.381,- \\
\hline & Output & Dana ZIS Tersalurkan & Rp. 75.455.582.788,- \\
\hline
\end{tabular}

Sumber: Laporan Keuangan LAZNAS Inisiatif Zakat Indonesia

Tabel 3.2 Variabel Outcome

(Pengukuran Tingkat Efektivitas)

\begin{tabular}{|c|c|c|}
\hline Tahun & Variabel & Jumlah Dana \\
\hline \multirow{2}{*}{2016} & Dana ZIS Tersalurkan & Rp. 32.037.792.810,- \\
\cline { 2 - 3 } & Target Penyaluran Dana ZIS & Rp. 62.550.073.983,- \\
\hline \multirow{2}{*}{2017} & Dana ZIS Tersalurkan & Rp. 55.453.648.037,- \\
\cline { 2 - 3 } & Target Penyaluran Dana ZIS & Rp. 60.570.599.886,-- \\
\hline \multirow{2}{*}{2018} & Dana ZIS Tersalurkan & Rp. 75.455.582.788,- \\
\cline { 2 - 3 } & Target Penyaluran Dana ZIS & Rp. 78.853.112.381,- \\
\hline
\end{tabular}

Sumber: Laporan Keuangan LAZNAS Inisiatif Zakat Indonesia

\subsection{Teknik Pengumpulan Data}

Teknik pengumpulan data pada penelitian ini menggunakan studi dokumentasi (kepustakaan). Dalam hal ini, studi dokumentasi dengan menggunakan data sekunder, yaitu sebuah data atau dokumen yang didapatkan dari tulisan atau olahan dari orang lain/lembaga lain.

\subsection{Teknik Analisis Data}

Analisis data dalam penelitian ini sesuai topik penelitian dibagi menjadi dua, yaitu metode Data Envelopment Analysis (DEA) guna menghitung efisisiensi kinerja lembaga dan rasio Allocation to Collection Ratio (ACR) untuk menghitung tingkat efektivitas lembaga. Pengukuran efisiensi penelitian ini menggunakan pendekatan intermediasi dikarenakan lembaga amil zakat merupakan lembaga perantara atau penghunbung (intermediatory) antara muzakki ataupun donatur dan para mustahik (penerima manfaat) yang membutuhkan. Asumsi model yang digunakan adalah asumsi CRS (Constant Return to Scale) dimana setiap lembaga amil pastinya berusaha dalam operasionalnya terkait pengumpulan dan pengalokasian dana ZIS mencapai skala optimal dan memberikan sumbangsih kontribusi yang konstan dari tahun ke tahun berikutnya. 
Dalam pengukuran tingkat efisiensi pada lembaga amil menggunakan bantuan software Data Envelopment Analysis (DEA). Secara matematis, formulasi DEA dapat diformulasikan dibawah ini, (Ascarya dan Yumanita, 2006):

Keterangan:

$$
\text { Efisiensi }=\frac{\sum_{t=1 \text { UiYis }}^{m}}{\sum_{i=1}^{m} v j X j s} \leq 1, \text { Ui dan } V j \geq 0
$$

$\mathrm{m}=$ output

$\mathrm{i}=$ input

$\mathrm{Ui}=\mathrm{s} \times 1$ jumlah bobot output

$\mathrm{Vj}=\mathrm{s} \times 1$ jumlah bobot input

Yis $=$ jumlah output yang ke $\mathrm{i}$ yang dihasilkan

$\mathrm{Xjs}=$ jumlah input yang ke $\mathrm{i}$ yang dihasilkan

Pertidaksamaan di atas memberikan makna bahwasanya suatu lembaga amil dikatakan memiliki kinerja efisien secara relatif jika nilai dualnya sama dengan 1 (efisien sempurna 100\%), sebaliknya apabila nilai dualnya kurang dari 1, maka dapat diartikan bahwa lembaga amil mengalami inefisiensi.

Pengukuran efektivitas pada penelitian ini menggunakan metode Allocation to Collection Ratio (ACR). Dalam perhitungannya, untuk dapat menilai efektivitas lembaga diperlukan beberapa data berupa dana ZIS terdistribusikan (realisasi pendistribusian dana ZIS) dan dana ZIS terkumpul (target pendistribusian dana ZIS) yang terdapat dalam laporan keuangan. Analisis perhitungan efektivitas suatu lembaga/organisasi dapat dirumuskan dibawah ini (Mahmudi, 2007):

$$
\text { Efektivitas }=\frac{\text { realisasi pendistribusian dana } Z I S}{\text { target pendistribusian dana } Z I S}
$$

Pengukuran tingkat efektivitas ini dapat dinilai melalui dokumen Zakat Core Principles $(\mathrm{ZCP})$ yang diterbitkan oleh Puskaz BAZNAS dengan berbagai macam tingkatannya. Hasil perhitungan rasio diatas menunjukkan sejauh mana lembaga amil dalam mengelola dan mendistribusikan dana ZIS yang telah terhimpun. Berikut ini kategori penilaian tingkat efektivitas pada lembaga amil (BAZNAS, 2017):

Tabel 3.3 Penilainan Tingkat Efektivitas ZCP

\begin{tabular}{|c|c|}
\hline Kategori & ACR \\
\hline Highly Effective & $\geq 90 \%$ \\
\hline Effective & $70 \%-89 \%$ \\
\hline Fairly Effective & $50 \%-69 \%$ \\
\hline Below Expectation & $20 \%-49 \%$ \\
\hline Ineffective & $<20 \%$ \\
\hline
\end{tabular}

Sumber: Outlook Zakat Indonesia 2017

\section{HASIL PENELITIAN}

Pengelolaan dana zakat, infak, dan sedekah di Indonesia diatur dalam Undang Undang No. 23 Tahun 2011. Sebagai lembaga intermediatory, seyogyanya memiliki kinerja yang efisien dan efektif. Dalam penelitian ini menggunakan data sekunder tersebut berupa laporan keuangan LAZNAS Inisiatif Zakat Indonesia periode tahun 2016 sampai tahun 2018. 


\subsection{Analisis Pengukuran Efisiensi LAZNAS Inisiatif Zakat Indonesia Periode 2016-2018}

Pengukuran tingkat efisiensi lembaga menggunakan metode Data Envelopment Analysis (DEA) dengan pendekatan intermediasi, asumsi CRS dan berorientasi input. Apabila hasil output nilai sebesar $100 \%$ atau 1 maka dikatakan efisien dan sebaliknya. Berikut ini hasil pengolahan data untuk mengukur tingkat efisiensi melalui software Warwick DEA dengan pendekatan intermediasi, asumsi CRS dan berorientasi input:

Tabel 4.1 Pengukuran Efisiensi LAZNAS Inisiatif Zakat Indonesia

\begin{tabular}{|c|c|c|}
\hline Tahun & Skor & Keterangan \\
\hline 2016 & $69,29 \%$ & Inefisiensi \\
\hline 2017 & $100 \%$ & Efisien \\
\hline 2018 & $100 \%$ & Efisien \\
\hline
\end{tabular}

Sumber: Hasil Output Warwick DEA (diolah)

Pada tahun 2016, kinerja LAZNAS Inisiatif Zakat Indonesia dalam pengelolaan dana zakat, infak, dan sedekah sebagai intermediatory antara muzakki/donatur dan mustahik atau yang membutuhkan menunjukkan adanya inefisiensi. Hasil output Wdea yang menunjukkan skor efisiensi pada tahun 2016 sebesar 69,29\%. Dengan ini, dapat diambil garis besar bahwa efisiensi LAZNAS Inisiatif Zakat Indonesia dapat meningkatkan lagi tingkat efisiensinya sebesar $30,71 \%$.

Sedangkan pada tahun 2017 dan 2018, LAZNAS Inisiatif Zakat Indonesia mencapai kinerja yang efisien. Hal ini dibuktikan melalui hasil skor pengukuran efisiensi yang berhasil dicapai sebesar $100 \%$ atau sama dengan 1. Untuk mengetahui lebih rinci penjelasan terkait tingkat efisiensi lembaga perlu adanya pengetahuan tentang variabelvariabel mana berikut komponennya yang menyebabkan terjadinya inefisiensi. Oleh karena itu, diperlukan adanya analisis terkait variabel-variabel yang ada melalui angka aktual dan angka proyeksi dari perhitungan yang dihitung oleh software DEA. Angka aktual yaitu nilai realisasi yang dimiliki atau diperoleh oleh LAZNAS Inisiatif Zakat Indonesia. Sedangan angka target yakni nilai yang seharusnya dicapai yang diproyeksikan oleh DEA. Jika nilai persentase To Gain sebesar 0\%, maka lembaga tidak perlu melakukan perubahan baik dari variabel input dan variabel output begitu sebaliknya.

Tabel 4.2 Angka Aktual \& Angka Target Efisiensi Inisiatif Zakat Indonesia 2016

\begin{tabular}{|c|c|c|c|}
\hline Variabel & Aktual (Rp) & Target (Rp) & To Gain \\
\hline $\begin{array}{c}\text { Biaya } \\
\text { Operasional }\end{array}$ & 6.551 .963 .732 & 4.540 .510 .866 & $30,7 \%$ \\
\hline $\begin{array}{c}\text { Dana ZIS } \\
\text { Terhimpun }\end{array}$ & 62.550 .073 .983 & 34.965 .491 .356 & $44,1 \%$ \\
\hline $\begin{array}{c}\text { Dana ZIS } \\
\text { Tersalurkan }\end{array}$ & 32.037 .792 .810 & 32.037 .792 .810 & $0 \%$ \\
\hline
\end{tabular}

Sumber: Hasil Output Warwick DEA (diolah) 
Berdasarkan tabel 4.3, LAZNAS Inisiatif Zakat Indonesia mengalami inefisiensi pada dua variable, yaitu biaya operasional dan dana ZIS terhimpun. Pada tahun 2016, biaya operasional yang dipakai lembaga menjalankan operasional selama satu tahun sebesar Rp. 6.551.963.732,-. Tetapi, proyeksi yang seharusnya dicapai oleh lembaga untuk menurut perhitungan DEA dalam bentuk angka target yakni sebesar Rp. 4.540.510.866,-. Atau dengan kata lain, biaya operasional dapat ditekan hingga 30,7\% untuk mencapai skor efisiensi sempurna.

Sedangkan pada dana ZIS terhimpun, LAZNAS Inisiatif Zakat Indonesia berhasil mengumpulkan dana ZIS tahun 2016 sebesar Rp. 62.550.073.983,- namun angka yang diproyeksikan oleh DEA yang seharusnya dicapai sebesar Rp. 34.965.491.356,. Untuk dana ZIS terhimpun ini, dalam perhitungan DEA diatas diproyeksikan bahwa dana ZIS terhimpun yang seharusnya dicapai (angka target) lebih kecil dari dana ZIS terhimpun yang terealisasi (angka aktual). Dengan ini dapat diartikan bahwa lembaga amil dalam proyeksi DEA harus menekan angka aktualnya. Hal ini menjadi tidak logis sebuah lembaga akan menekan jumlah dana ZIS terhimpun yang sudah berhasil diperoleh. Oleh karena itu, dalam analisa tahun 2016, seharusnya LAZNAS Inisiatif Zakat Indonesia dapat meningkatkan variabel dana ZIS tersalurkan dan menekan biaya operasional lembaga untuk mencapai efisiensi sempurna agar tidak ada penekanan/pengurangan dari dana ZIS terhimpun yang diproyeksikan oleh DEA.

Tabel 4.3 Angka Aktual \& Angka Target Efisiensi Inisiatif Zakat Indonesia 2017

\begin{tabular}{|c|c|c|c|}
\hline Variabel & Aktual (Rp) & Target (Rp) & To Gain \\
\hline $\begin{array}{c}\text { Biaya } \\
\text { Operasional }\end{array}$ & 7.857 .919 .503 & 7.857 .919 .503 & $0 \%$ \\
\hline $\begin{array}{c}\text { Dana ZIS } \\
\text { Terhimpun }\end{array}$ & 60.570 .599 .886 & 60.570 .599 .886 & $0 \%$ \\
\hline $\begin{array}{c}\text { Dana ZIS } \\
\text { Tersalurkan }\end{array}$ & 55.453 .648 .037 & 55.453 .648 .037 & $0 \%$ \\
\hline
\end{tabular}

Sumber: Hasil Output Warwick DEA (diolah)

Tabel 4.4 Angka Aktual \& Angka Target Efisiensi Inisiatif Zakat Indonesia 2018

\begin{tabular}{|c|c|c|c|}
\hline Variabel & Aktual (Rp) & Target (Rp) & To Gain \\
\hline $\begin{array}{c}\text { Biaya } \\
\text { Operasional }\end{array}$ & 11.287 .389 .442 & 11.287 .389 .442 & $0 \%$ \\
\hline $\begin{array}{c}\text { Dana ZIS } \\
\text { Terhimpun }\end{array}$ & 78.853 .112 .381 & 78.853 .112 .381 & $0 \%$ \\
\hline $\begin{array}{c}\text { Dana ZIS } \\
\text { Tersalurkan }\end{array}$ & 75.455 .582 .788 & 75.455 .582 .788 & $0 \%$ \\
\hline
\end{tabular}

Sumber: Hasil Output Warwick DEA (diolah)

Skor akhir efisiensi yang diperoleh oleh LAZNAS Inisiatif Zakat Indonesia tahun 2017 dan tahun 2018 sebesar 100\% atau sama dengan 1. Ini berarti sebagai lembaga intermediator antara muzakki/donatur dan mustahik atau yang membutuhkan, LAZNAS Inisiatif Zakat Indonesia berhasil melakukan pengelolaan dana ZIS dengan baik dan efisien. Semua variabel input yang terdiri dari biaya operasional dan dana ZIS terhimpun 
serta variabel output yang terdiri dari dana ZIS tersalurkan memiliki angka aktual dan angka target/proyeksi yang sama.

\subsection{Analisis Pengukuran Efektivitas LAZNAS Inisiatif Zakat Indonesia Periode 2016-2018}

Allocation to Collection Ratio ini menghitung dan menjelaskan yang hubungannya dengan jumlah dana ZIS yang dialokasikan dengan jumlah dana ZIS yang dikumpulkan. Yang perlu dipahami dalam perhitungan rasio ini, semakin besar persentase perbandingan rasio maka semakin besar kapasitas penyaluran dan penghimpunan dana ZIS. Semakin besar kapasitas penyaluran dan penghimpunan dana ZIS yang dilakukan oleh lembaga amil zakat maka semakin besar tingkat efektivitas lembaga tersebut dalam menjalankan operasionalnya dalam hal penyaluran dan penghimpunan dana ZIS. Semakin besar tingkat efektivitas dan kapasitas penyaluran dana, maka semakin besar pula manfaat/kegunaan yang dirasakan masyarakat mustahik yang membutuhkan.

Tabel 4.5 Pengukuran Efektivitas LAZNAS Inisiatif Zakat Indonesia

\begin{tabular}{|c|c|c|}
\hline Tahun & Persentase & Kategori \\
\hline 2016 & $51 \%$ & Fairly Effective \\
\hline 2017 & $92 \%$ & Highly Effective \\
\hline 2018 & $96 \%$ & Highly Effective \\
\hline \multicolumn{3}{|c|}{ Sumber: Peneliti, diolah }
\end{tabular}

Tingkat efektivitas yang diperoleh LAZNAS Inisiatif Zakat Indonesia pada tahun 2016 memperoleh predikat "Fairly Effective" berdasarkan kriteria tingkat penilaian efektivitas dalam Zakat Core Principles dengan perolehan nilai sebesar 51\%. Hal ini berarti Inisiatif Zakat Indonesia pada tahun 2016 dapat menyerap dana ZIS di masyarakat sebesar 51\% dari jumlah target pendistribusian. Hal ini bisa didefinisikan bahwa penyaluran dana ZIS oleh Inisiatif Zakat Indonesia dapat terserap sebesar separuh dari target dan masih perlu adanya perbaikan ke depan yang lebih baik untuk dapat meningkatkan predikat diatasnya. Mengingat sebelumnya pada awal tahun 2016 merupakan awal mula dimana LAZNAS Inisiatif Zakat Indonesia menjalankan operasionalnya dalam pengelolaan dana ZIS sebagai LAZ skala nasional. Dalam awal tahun bermulainya operasional lembaga, Inisiatif Zakat Indonesia perlu menyiapkan kebutuhan dan keperluan kedepan dalam menunjang kegiatan operasional khususnya yang berkaitan dengan penilaian tingkat efektivitas, seperti survei muzakki dan survei mustahik.

Tingkat efektivitas yang diperoleh LAZNAS Inisiatif Zakat Indonesia pada tahun 2017 memperoleh predikat "Highly Effective" berdasarkan kriteria tingkat penilaian efektivitas dalam Zakat Core Principles dengan perolehan nilai 92\%. Hal ini juga menunjukkan peningkatan tingkat efektivitas yang lebih efektif dibanding tahun sebelumnya yakni tahun 2016 dimana IZI hanya dapat menyerap dana pendistribusian sebesar $51 \%$.

Tingkat efektivitas yang diperoleh LAZNAS Inisiatif Zakat Indonesia pada tahun 2018 berdasarkan kriteria tingkat penilaian efektivitas dalam Zakat Core Principles, yaitu "Highly Effective" dengan perolehan nilai 96\% lebih besar dari tahun sebelumnya. Angka ini mengartikan bahwa LAZNAS Inisiatif Zakat Indonesia berhasil menjalankan 
operasional pengelolaan dana ZIS dalam hal penyaluran dana sebesar 96\% dari target pendistribusian yang berhasil dihimpun. Dengan kata lain, implikasinya semakin besar kapasitas penyaluran dan penghimpunan dana ZIS yang dilakukan oleh lembaga amil zakat maka semakin besar tingkat efektivitas lembaga tersebut dalam menjalankan operasionalnya dalam hal penyaluran dan penghimpunan dana ZIS. Semakin besar tingkat efektivitas dan kapasitas penyaluran dana, maka semakin besar pula manfaat yang dirasakan masyarakat mustahik yang membutuhkan.

\section{KESIMPULAN}

Berdasarkan pengolahan dan analisa data melalui software Data Envelopment Analysis (DEA) dan rasio Allocation to Collection Ratio (ACR), penulis dapat menyimpulkan beberapa poin kesimpulan, yaitu:

a. Hasil pengukuran tingkat efisiensi yang diperoleh LAZNAS Inisiatif Zakat Indonesia dari tahun ke tahun berfluktuatif dengan tren positif dari tahun ke tahun.

1) Pada tahun 2016, terjadi inefisiensi lembaga dengan perolehan skor sebesar 69,29\% (kurang dari 100\%). Inefisiensi dapat terjadi disebabkan pada biaya operasional dan dana ZIS terhimpun. Lembaga dapat melakukan perubahan dengan cara mengurangi penggunaan atas kedua variabel tersebut.

2) Pada tahun 2017 dan 2018, lembaga telah berhasil mencapai tingkat efisiensi $100 \%$ atau efisiensi maksimal dalam pengelolaan dana zakat, infak, dan sedekah. Tidak perlu melakukan perubahan baik dari variabel input maupun output dikarenakan nilai To Gain bernilai $0 \%$.

b. Hasil pengukuran tingkat efektivitas yang diperoleh oleh LAZNAS Inisiatif Zakat Indonesia dari tahun ke tahun dengan mengacu Zakat Core Principles mengalami peningkatan tren positif. Pada tahun 2016, tingkat efektivitas yang berhasil dicapai sebesar 51\% sehingga mendapat predikat "Fairly Effective". Hal ini dapat didefinisikan bahwa pendistribusian dana ZIS oleh Inisiatif Zakat Indonesia dapat terserap sebesar separuh dari target dan masih perlu adanya perbaikan. Namun, pada tahun 2017 berhasil meningkatkan tingkat efektivitas disbanding tahun sebelumnya dengan perolehan skor sebesar 92\% sehingga memperoleh predikat "Highly Effective”. Pada tahun 2018, juga mengalami peningkatan skor tingkat efektivitas sebesar 96\% dengan predikat "Highly Effective". Dengan ini, banyaknya dana ZIS terserap dan tersalurkan kepada masyarakat mustahik maka semakin besar pula manfaat yang dapat dirasakan dan berguna bagi mereka.

\section{DAFTAR PUSTAKA}

Aam Slamet Rusydiana dan Salman Al Farisi. (2016). The Efficiency of Zakah Institutions Using Data Envelopment Analysis. Al-Iqtishad: Journal of Islamic Economics, 8(2). 
Ambar Teguh Sulistiyani \& Rosidah. (2009). Manajemen Sumber Daya Manusia. Yogyakarta: Graha Ilmu.

Ascarya \& DianaYumanita. (2006). Analisis Efisiensi Perbankan Syariah di Indonesia dengan DEA. TAZKIA: Islamic Finance and Business Review , 1(2).

Badan Amil Zakat Nasional. (2017). Outlook Zakat Nasional 2017. Jakarta: Puskas BAZNAS.

Badan Pusat Statistik. (2019). Persentase Penduduk Miskin Maret 2019 Sebesar 9,41 Persen. https://www.bps.go.id/pressrelease/2019/07/15/1629/persentase-pendudukmiskin-maret-2019-sebesar-9-41-persen.html , Diakses pada 15 Januari 2020.

Clarashinta Canggih, dkk. (2017). Potensi dan Realisasi Dana Zakat Indonesia. Al-Uqud: Journal of Islamic Economics, 1(1).

Coelli,T.J., D.S. P. Rao, C.J. O’Donnell, and G.E. Battese. (2005). An Introduction to Efficiency and Productivity Analysis Second Edition. Springe. New York.

Dwi Hadya. (2019). Jumlah Penduduk Indonesia 269 Juta Jiwa, Terbesar Keempat di Dunia. Tersedia di https://databoks.katadata.co.id/datapublish/2019/04/29/jumlahpenduduk-indonesia-269-juta-jiwa-terbesar-keempat-dunia , Diakses pada 15 Januari 2020.

Mahmudi. (2007). Manajemen Kinerja Sektor Publik. Yogyakarta: Unit Penerbit dan Percetakan.

Rachma Indrarini dan Clarashinta Canggih. (2019). Efficiency Of Islamic Insurance In Indonesia. Jurnal Iqtishoduna, 8(2).

Rusmini \& Tony Seno Aji. (2019). Efisiensi Kinerja Lembaga Amil Zakat Dalam Mengelola Dana ZIS Dengan Metode DEA (Studi Pada YDSF Surabaya). Jurnal Zakat dan Wakaf STAIN Kudus, 6(2).

Siti Nur Azizah. (2018). Efektivitas Kinerja Keuangan Badan Amil Zakat Nasional (BAZNAS) Pada Program Pentasharufan Dana Zakat Di BAZNAS Kota Yogyakarta. Jurnal Ekonomi Islam el-JIZYA, 6(1).

Siti Nurhasanah \& Deni Lubis. (2017). Efisiensi Kinerja BAZNAS Bogor Dan Sukabumi: Pendekatan Data Envelopment Analysis. Jurnal Akuntansi dan Keuangan Islam ,5(2).

Sondang P. Siagian. (2001). Manajemen Sumber Daya Manusia. Jakarta: Bumi Aksara.

Tim Publikasi Katadata. (2019). Potensi Ratusan Triliun, Pengumpulan Zakat Digital Makin Gencar. Tersedia di https://katadata.co.id/berita/2019/05/27/potensi- 


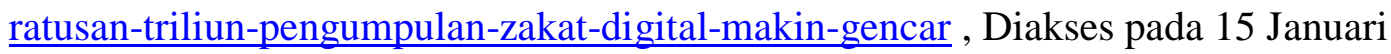
2020.

Undang Undang Nomor 23 Tahun 2011 Tentang Pengelolaan Zakat. Tersedia di https://kalteng.kemenag.go.id/file/file/GONDO/5121567496646.pdf, Diakses pada 15 Januari 2020.

Viva Budy. (2019). Indonesia, Negara dengan Penduduk Muslim Terbesar Dunia. Tersedia di https://databoks.katadata.co.id/datapublish/2019/09/25/indonesianegara-dengan-penduduk-muslim-terbesar-dunia , Diakses pada 15 Januari 2020. 